\title{
An Innovative Universal Screw Removal Instrument
}

\author{
Mehmet Elmadağ ${ }^{1}$, Yunus Güzel ${ }^{2}$, Gökçer Uzer ${ }^{1}$, Mehmet Ali Acar $^{3}$ \\ ${ }^{I}$ Department of Orthopaedics and Traumatology, Bezmialem Vakif University School of Medicine, Istanbul, \\ ${ }^{2}$ Department of Orthopaedics and Traumatology, Ordu University School of Medicine, Ordu \\ ${ }^{3}$ Department of Orthopaedics and Traumatology, Selçuk University Selçuklu School of Medicine, Konya, Turkey
}

Objective: To present the clinical benefits of an instrument designed to facilitate removal of polyaxial screws during revision surgery.

Methods: All polyaxial screws can be removed without additional materials or a large amount of debridement using our newly designed instrument. Forty-two screws were removed from five patients without any complications using this instrument. Results: We removed the cap screws and rods from the 42 polyaxial screws in five patients and made them monoaxial using the new screw removal apparatus. The screws and rods were removed quickly in a minimally invasive way with no complications. No damage to the pedicle or surrounding soft tissue occurred during screw removal. No neurogenic changes developed during revision surgery after changing the screws.

Conclusion: This newly designed screw removal instrument was used safely and effectively to remove all polyaxial and monoaxial pedicle screws.

Key Words: Pedicle screws $\cdot$ Spinal fusion $\cdot$ Spine $\cdot$ Equipment failure

\section{INTRODUCTION}

A large increase in fusion rates for spine surgery has been observed in the last 20 years ${ }^{9}$, and the frequency of revision spine surgery continues to increase. The most common reasons for additional surgery ${ }^{7}$ following fusion surgery are implant complications and pseudoarthrosis.

It is necessary to remove and change the existing implants during revision surgery. The keyholes inside each screw brand (particularly polyaxial screws) are different. They may be in the shape of a male or female rectangle or hexagonal, octagonal, or star-shaped. Therefore, it is necessary to have the instrument set used during the first operation or to have an appropriate screwdriver available. This is not always possible and in some

- Received: October 2, 2014 - Revised: January 28, 2015

- Accepted: February 11, 2015

Corresponding Author: Yunus Güzel, MD

Department of Orthopaedics and Traumatology, Ordu University

School of Medicine, ORDU, Turkey

Tel: +90-505-699-63-68, Fax: +90-452-226-52-28

E-mail: dryg@windowslive.com

*The authors declare that they have no conflicts of interest and source of funding.

®This is an Open Access article distributed under the terms of the Creative Commons Attribution Non-Commercial License (http://creativecommons.org/ licenses/by-nc/3.0/) which permits unrestricted non-commercial use, distribution, and reproduction in any medium, provided the original work is properly cited. circumstances the implant may no longer be in production.

When revision surgery studies were examined ${ }^{5,12)}$, methods to remove broken screws are reported but very little information related to removing normal screws has been provided. No previous report has described a single-piece screw remover to remove normal screws. A small part of the rod is cut and placed in the screw when a removal set is not available. After tightening the screw head, mobile screw's head become monoblock screws. This screw is a single piece that can be removed by hand or with pincers ${ }^{10)}$. The polyaxial remover presented here requires only a cap-screw screwdriver to remove the polyaxial screws. Due to the structure of the remover and the method, existing screws can be removed with minimal dissection of surrounding soft tissue.

Surgical techniques for revising the spine take longer than those of primary spine surgery. Debridement is important to remove scars, envision the bone elements, and prepare a new fusion bed during revision surgery. Extended operating time increases blood loss and infection risk ${ }^{8)}$. Additional procedures applied to remove screws cause the surgeon to expend extra effort, which may lead to loss of time. Our tool simplifies and accelerates the screw removal process; thus, shortening operating time. There is also a need for large metal cutters to cut rods. The aim of our polyaxial screw remover design is to facilitate screw removal and thereby reduce blood loss, infection risk, cost, and effort expended by the surgeon. 


\section{MATERIALS AND METHODS}

The patient demographic data and reasons for primary and revision surgery are given in Table 1 . The aim when removing polyaxial screws is to stabilize the polyaxial head so the screw becomes monoaxial and can be removed by turning. The method described by Kose et al. ${ }^{6}$ was of benefit when we designed our instrument, which has not been described previously in the literature. In the method of Kose et al., the screw becomes monoaxial with a rod and cap screw, whereas we used a U-shaped end section in our instrument without the need for a rod.

The polyaxial remover consists of a single-piece shaft, sleeve, and handle (Fig. 1A, B). The shaft section is hollow, and the screw cap is tightened with a screwdriver. The Ushaped end section has a narrower structure (Fig. 1B). Thus, a spine screw enters easily, and the surgeon avoids damaging surrounding tissue.

The head section of a polyaxial screw was removed, and
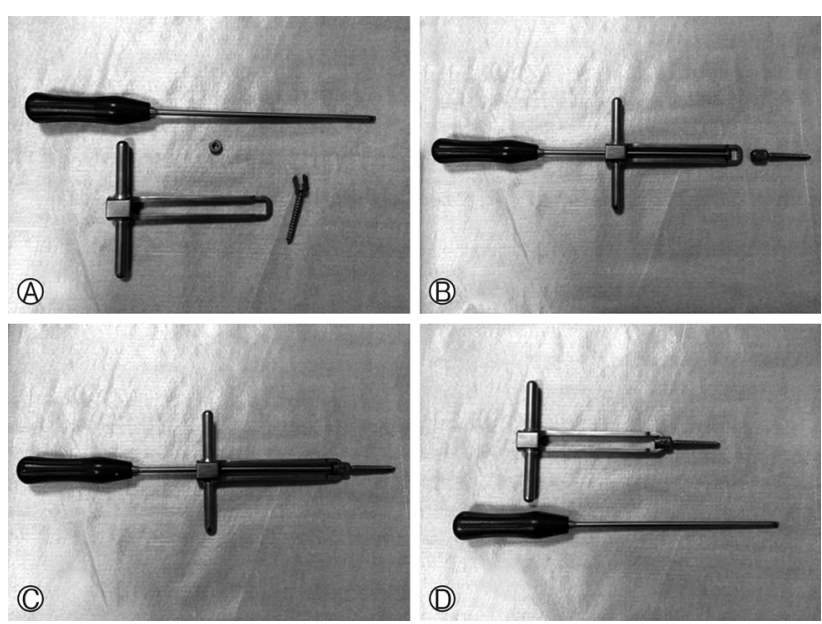

Fig. 1. The polyaxial remover technique. the screw was placed in the U-section (Fig. 2). The cap screw was tightened on the screw, and the screw was fixed in the end section of the apparatus. The polyaxial screw that became monoaxial can be removed by turning the handles on the shaft. Thus, the need for metal cutters and extra time and effort is avoided. This method also removes the need to clean the fibrous tissue covering the internal screws and to see the screw shape.
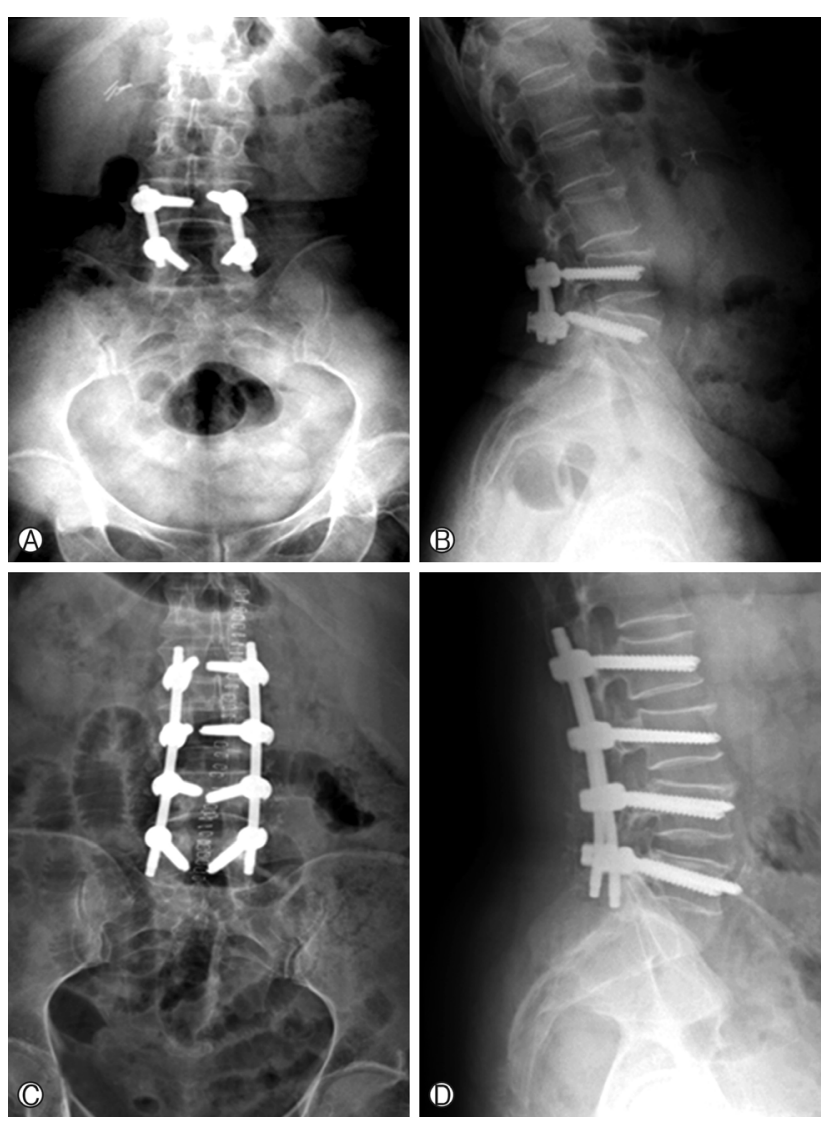

Fig. 2. (A) Anteroposterior (AP) radiograph of a patient operated on for spinal stenosis, (B) Lateral radiograph, (C) AP radiograph after revision surgery, (D) Lateral radiograph.

Table 1. Patient demographic data, reasons for primary and revision surgery, and number of screws removed

\begin{tabular}{|c|c|c|c|c|c|c|c|}
\hline Case & Gender & $\begin{array}{l}\text { Age } \\
\text { (year) }\end{array}$ & $\begin{array}{l}\text { Reason for primary } \\
\text { surgery }\end{array}$ & Reason for revision & $\begin{array}{l}\text { Time to revision } \\
\text { (months) }\end{array}$ & $\begin{array}{l}\text { Number of screws removed } \\
\text { (not including broken screws) }\end{array}$ & $\begin{array}{l}\text { Number of screws } \\
\text { used after revision }\end{array}$ \\
\hline 1 & $\mathrm{~F}$ & 71 & $\begin{array}{l}\text { Spinal stenosis }+ \\
\text { degenerative scoliosis }\end{array}$ & $\begin{array}{l}\text { proximal junctional } \\
\text { kyphosis }\end{array}$ & 12 & 14 screws & 22 screws \\
\hline 2 & $\mathrm{~F}$ & 69 & Spinal stenosis & infection & 6 & 4 screws & 16 screws \\
\hline 3 & $F$ & 58 & Vertebral fracture & implant failure & 28 & 8 screws & 18 screws \\
\hline 4 & $\mathrm{~F}$ & 66 & Spinal stenosis & $\begin{array}{l}\text { proximal junctional } \\
\text { kyphosis }\end{array}$ & 9 & 10 screws & 16 screws \\
\hline 5 & $\mathrm{~F}$ & 75 & Spinal stenosis & Re-stenosis & 34 & 6 screws & 8 screws \\
\hline
\end{tabular}




\section{RESULTS}

A total of 42 polyaxial screws were removed from five patients with the new single-piece screw remover (Fig. 2) (Table 1). The pedicle and surrounding soft tissue were not damaged during screw removal. The polyaxial cap screws were 4.5 hexagonal screws in four patients and star-shaped in one patient. After removing the cap screws and rods, all of the polyaxial screws were made monoaxial with the instrument described above and were removed rapidly in a minimally invasive way with no complications. No neurogenic changes developed during surgery.

\section{DISCUSSION}

We have described a screw removal instrument designed to overcome the problems of screw removal often encountered during revision surgery. Our clinical application shows that these screws can be removed without the need for additional materials or soft tissue debridement within or below the screw head.

The correct screwdriver for the materials used cannot always be obtained to remove existing implants during revision surgery because of the different designs. Therefore, additional techniques and materials are required. This explains why revision surgery can be a longer and more fatiguing operation with increased blood loss.

Of the several known spine surgery problems, the most accepted and most widely used method for repair is pedicle screw fixation ${ }^{1,2-11)}$. After fixation, the most common reasons for revision surgery ${ }^{7}$ are implant problems and pseudoarthrosis. Implant failure ${ }^{3,4)}$ has been reported at rates of 3$12 \%$. Methods and instruments to remove broken screws have been described in the literature ${ }^{5,12)}$. However, no additional methods ${ }^{6,10)}$, other than the rod techniques for removing normal screws, have been described. In the U-rod technique described by Köse et al. ${ }^{6}$, the cap screws are removed with an Allen key, and the screw is placed in the U-shaped rod after removing the rods. After tightening the screw head, the screw with a mobile head becomes a monoblock screw. This single-structure screw can be removed by hand or with pincers. All of these procedures result in extra effort, leading to loss of time. Cutting rods in good condition is a loss of material. In addition, large metal cutters are required to cut the rods, a rod bender is needed to shape, and pincers are needed to turn the rod placed on the screw head. Our screw remover design is a single piece and will not damage surrounding tissue or the pedicle (Fig. 1A, B). There is no need for metal cutters or a rod bender; thus, reducing the time and effort required. The tool also removes the need to clean the fibrous tissue covering the internal screws to determine screw shape. Thus, bleeding associated with debridement of fibrous tissue is prevented.

There were several limitations to this study. First, the number of patients was relatively small. Second, a polyaxial remover was used after removing the cap screws, so it was necessary to have a screwdriver suitable for the cap screws. However, cap screws are generally hexagonal or star-shaped and there are few varieties. These screws are generally found in sets, or the screwdriver in the revision set can be used. Another limitation was that the polyaxial remover could not be used if the cap screw is damaged or broken.

The screw removal technique using the polyaxial remover is practical and easy and requires a minimal amount of time. As presented here, 42 screws were removed from five patients without any complications. A polyaxial remover or a similar instrument has not been reported previously. This newly designed polyaxial remover is recommended for use in all revision vertebral surgeries.

\section{CONCLUSION}

The instrument described here can be used to remove all types of polyaxial and monoaxial screws used in spine surgery. here is no requirement for additional screw removal tools or materials and unnecessary debridement is avoided.

\section{REFERENCES}

1. Bridwell KH, Sedgewick TA, O'Brien MF, Lenke LG, Baldus $\mathrm{C}$ : The role of fusion and instrumentation in the treatment of degenerative spondylolisthesis with spinal stenosis. J Spinal Disord 6:461-472, 1993

2. Boos N, Webb JK: Pedicle screw fixation in spinal disorders: a European view. Eur Spine J 6:2-18, 1997

3. Esses SI, Sachs BL, Dreyzin V: Complications associated with the technique of pedicle screw fixation. A selected survey of ABS members. Spine (Phila Pa 1976) 18:2231-2238, 1993

4. Jutte PC, Castelein RM: Complications of pedicle screws in lumbar and lumbosacral fusions in 105 consecutive primary operations. Eur Spine J 11:594-598, 2002

5. Kaya AH, Dagcinar A, Celik F, Senel A: Simple technique for removing broken pedicular screw with plain and serviceable screw driver. Eur Spine J 17:1116-1118, 2008

6. Kose KC, Isik C, Altinel L, Ates A, Ozdemir M: Easy retrieval of polyaxial tulip-head pedicle screws by " $U$ " rod technique. Eur Spine J 19:144-146, 2010 
7. Martin BI, Mirza SK, Comstock BA, Gray DT, Kreuter W, Deyo RA: Reoperation rates following lumbar spine surgery and the influence of spinal fusion procedures. Spine 32:382-387, 2007

8. Ma Y, Passias P, Gaber-Baylis LK, Girardi FP, Memtsoudis SG: Comparative in hospital morbidity and mortality after revision versus primary thoracic and lumbar spine fusion. Spine J 10:881889, 2010

9. Rajaee SS, Bae HW, Kanim LE, Delamarter RB: Spinal fusion in the United States: analysis of trends from 1998 to 2008. Spine
37:67-76, 2012

10. Ulus A, Kaya AH, Bayri Y, Dagcinar A, Sataloglu H, Senel A: Poly-axial screw removal. Cent Eur Neurosurg 71:108-109, 2010

11. Weinstein JN, Lurie JD, Olson PR, Bronner KK, Fisher ES: United States' trends and regional variations in lumbar spine surgery. Spine 31:2707-2714, 2006

12. Weng X, Qiu G, Li J, Li S, Lee CI, Yu B, et al: An innovative broken pedicle screw retrieval instrument. J Spinal Disord Tech. 20:82-84, 2007 